\title{
'Spiritual life' as the heart of the professionalization process of Spiritual and Community Animators in Quebec, Canada
}

\author{
Jacques Cherblanc ${ }^{12}$ and Marie-Anne Risdon ${ }^{2}$ \\ ${ }^{1}$ Centre for Inter-University Research on the Learning Framework for the Teaching Profession, \\ University of Quebec, Canada; ${ }^{2}$ Laboratory of Expertise and Research in Ritual and Symbolic \\ Anthropology, University of Quebec, Canada
}

\begin{abstract}
The 'spiritual care and guidance and community involvement service' in Quebec has existed since 2001. It replaced pastoral animation in schools and is intended to promote the spiritual development and community involvement of all students, whether or not they are affiliated with a religion. This article presents the historical background that led to the development of this service; as well as the professional concerns of its stakeholders. The concerns raised are based on awareness of great diversity among those who provide this service, both in their training and in their understanding of the meanings of the terms that define their work. Presently working toward the professionalization that they deem essential to their very survival, they are using professional strategies that do not reflect their reality and abilities. This article seeks to demonstrate the relevance of changing perspectives so that this profession is not limited only to community involvement, but instead adopts an interactionist point of view, focused on the spiritual aspect of the role.
\end{abstract}

KEYWORDS Quebec, education, spiritual animation and community involvement service, professionalization, interactionism

\section{Introduction}

In Anglo-Saxon countries, interest in spirituality is widely shared within the education sector. Indeed, the need to foster pupils' spiritual development is integrated into many school systems. (Roehlkepartain et al. 2006; Carr and Haldane 2003; Erriker and Erriker 2001; Wenman 2001). This relationship between education and spiritual development is based on a humanistic vision of education that aims to increase the student's wellness (De Souza 2016; Wane et al 2011; Miller et al. 2005; Glazer 1999; Best 1996). In this context, spirituality is usually described as a process of personal growth, marked by a feeling of transcendence - a relationship to the sacred - which allows a more integrative approach to the education of children and adolescents through a holistic vision of their development (body, mind and spirit).

Since 2000, Quebec public schools, sharing this broader vision, have had a new obligation to facilitate the spiritual development of students. While elsewhere this responsibility often relies on teachers, in Quebec a profession was created specifically to facilitate students' spiritual development: Spiritual Care and Guidance and Community Involvement Animators (SCGCIAs). Their roles are to facilitate the spiritual journey of students, regardless of their religious affiliation, as well as to help students to contribute to the development of a harmonious society. This type of spiritual accompaniment outside of any religious affiliation appears to be 
unique in the world, especially in school settings. It should facilitate each student's spiritual journey. However, the particularities of this profession bring some special challenges.

SCGCIAs are in a rather new situation in the history of professions. They are officially considered professionals, given their title and job status, yet they have few of the characteristics that are usually expected of a profession: they do not have specific university training, mutual scientific knowledge, a reserved area of practice, a code of ethics, or a professional order. This puts them in a weak position as it allows authorities to cut jobs or require certain acts for which they are not responsible, especially given the current context of budgetary restrictions. This causes tensions and a certain competition among stakeholders to have their relevance within each school or school board recognized.

To highlight their professional purpose and development, some one hundred SCGCIAs came together to create a professional association: the Association professionnelle des animateurs et animatrices de vie spirituelle et d'engagement communautaire du Québec (APAVECQ) ${ }^{1}$. The Association has been working to improve the perception of the service, thus hoping to ensure greater recognition for its members academically, socially and politically. APAVECQ's current "professional strategy' is rather traditional and based on an approach from when members were pastoral animators. They were then supported by an official religious structure that organized the identification and dissemination of shared knowledge taught in university theology and religious studies faculties, and therefore the reinforcement of a professional identity and practice. Their professional status was thus assigned by 'outside' forces: it was the church and the state that structured the profession (competencies, training, practices, etc.).With the deconfessionalization of the school system ${ }^{3}$, the church no longer had any influence on the definition of the role of the AVSEC. However, APAVECQ has in large part remained in this submissive position in relation to the demands and expectations of the state.

So, since the fall of 2014, the goal of APAVECQ has been to abandon one of the two constitutive aspects of the SCGCIA intervention, namely 'spiritual life', since this is deemed too problematic by schools; and to emphasise the 'community involvement' aspect of the professional title as it seems to be more consensual. Thus, during the 2015 APAVECQ Convention, it was proposed that the SCGCIA professional title be replaced by a shorter title that would emphasize community involvement: 'citizenship advisor' ${ }^{4}$. We see here how the identity of these SCGCIAs is malleable to fit the demands (or perceptions) of the various settings in which they work.

Faced with this movement toward professionalization focused on the 'de-spiritualization' of the SCGCIA, this article proposes a professional strategy (based on form and content) that is the complete opposite of that currently used by the APAVECQ. We intend to show that SCGCIAs would benefit from using a professionalization method that draws on an interactionist approach (Demazière and Gadéa 2009). This approach considers that a profession is gradually and contingently defined around a territory of reserved practice which is recognized socially.

\footnotetext{
${ }^{1}$ The APAVECQ website is at: http://www.apavecq.qc.ca/ [Accessed 11/07/2019]

${ }^{2}$ Or 'Professional Project' according to Sarfati-Larson (1997).

${ }^{3}$ The deconfessionalization of school system structures occurred in the late 1990s; that of educational programs and services followed in the early 2000s. It was at this point that the Catholic or Protestant pastoral animation was replaced by the new service of spiritual accompaniment and secular community involvement, i.e. it became nonconfessional (Comité sur les affaires religieuses 2007, 23-37).

${ }^{4}$ This proposal, which failed to reach consensus and was not adopted, was presented as a reaction to the lack of openness of the Minister of Education at the time, who had clearly expressed deep concern about spirituality and its place in schools in front of certain representatives of the APAVECQ.
} 
This territory is built on knowledge in action, based on practice and experience, and benefits from internal definitions of experienced practitioners rather than on exterior and fixed standards. So, from this perspective, the best professional strategy for the SCGIAs would be to define a reserved practice and to make it socially recognized. This strategy would enable the SCGCIA concerned to consider the special nature of their history, the vast differences of their profiles and, especially, the more specific aspect of their area of intervention: the spiritual development of students.

\section{Methodology}

This article presents both a historical (based on a literature review) and current (based on empirical work) look at the SCGCIAs profession. The literature review includes scientific as well as government documentation. The empirical work comprises two studies led by the authors of this article: (1) the results of research led by the first author and conducted among Quebec SCGCIAs (SSHRC ${ }^{5}$ 2011-2016) and (2) the results of a focus group, led by the second author, as part of her doctoral research.

The aim of the SSHRC-funded research was to produce a grounded theory of spiritual practice among Quebec SCGCIAs. The practice narrative, a qualitative method, was used in this study. Practice narrative is a method that belongs to the life-stories model, a qualitative methodology that fits within the sociological practice of ethnomethodology initiated in the 1950s (Garfinkel 1984). It is a technique of objectification that consists of putting into words a personal experienced lived in the professional environment, once it has been concluded. A narrative practice is a story that is told with the details necessary for others to grasp the situation (see Bertaux, 1976). A total of 16 SCGCIAs produced practice narratives: 12 in a written form; 4 in an oral form in the context of a narrative interview ${ }^{6}$.

In both cases, the practice narratives were required to focus on specific practices that participants considered spiritual. The story was to be in three parts: a) the origin of the practice; b) the actualization of the practice; and c) the evaluation of the practice. Through the story, participants were also encouraged to report turning points in their practice as well as to make links between their practice and the academic training they had received. They were asked to be specific about the spiritual elements of the practice they described, in particular to explain why they were 'the only ones to be able to do this kind of work', 'to hold a particular expertise in their establishment', or in what ways this practice was not 'psychological' or 'religious'.

In addition to the practice narratives, participants were also asked to: (1) describe a typical day of work, and (2) complete a socio-demographic questionnaire. These data were then analysed thematically using the NVivo software (Version 11) to develop a theorization of what we have called the 'practiced spiritual'. For the purpose of triangulation, the result of this thematic analysis was presented for comments and criticism to the APAVECQ stakeholders (at meetings of the Board of Directors). This has led to new data collections, conceptual changes and new encounters, in an iterative process of recognition by stakeholders (Paillé and Mucchielli 2003, 185). Following the first presentation, stakeholders considered the image that emerged from the

\footnotetext{
${ }^{5}$ This research was financed by the Social Sciences and Humanities Research Council of Canada (SSHRC). ${ }^{6}$ The oral form was added to the written one after having encountered recruitment difficulties. An invitation was sent out in the fall of 2011 to all Quebec SCGCIA (members of the APAVECQ or not) to participate in a study on their professionalization. Of the 200 SCGCIAs invited to participate, only 7 people answered favorably. Some who declined to participate said that producing a written story was too time consuming.
} 
first seven narratives collected to be unrepresentative and wished to reiterate a request to participate in research among its members. Two more reminders were sent to the SCGCIAs, which enabled us to include 12 SCGCIAs at the end of the collection, i.e. in the winter of 2016. The same year, results of this second analysis were presented twice to 60 SCGCIAs and they confirmed the theorization proposed.

The aim of the doctoral research was to clarify the concept of spiritual life ${ }^{7}$. During the 2015 APAVECQ Convention a focus group was held with 20 SCGCIAs. As part of an appreciative enquiry, ${ }^{8}$ as developed by Cooperrider and Whithney (2005), these 20 SCGCIAs identified common elements of the analysis of spiritual interventions considered to be really effective. They then stated what they meant by 'spiritual life' and described their intervention methods. These affirmative statements shed light on what they believe forms the heart of their specific professional expertise and practice.

\section{From school pastoral care to a 'Spiritual Care and Guidance and Community Involvement Service': breaks and continuities}

Canada is a federation that is composed of 10 provinces and three territories. Each province enjoys great administrative autonomy, namely to manage health, cultural and school establishments. The Canadian education system is therefore characterized by wide diversity. Inspired by the United States model in its local and regional governance, it places considerable importance on parents' choices, namely to the recognition of rights and freedoms, including religious ones. Section 93 of the Canadian Constitution gives provinces full authority on educational matters while obliging them to protect Protestant and Catholic minorities. This historical obligation can be explained by the religious tensions of the time. It has deeply shaped the education systems of each province.

Quebec has a specific identity, which sets it apart from the rest of Canada, because of the mainly Francophone character of its inhabitants and a strong nationalist sentiment. Moreover, since 2016, 'les Québécois' (Quebecers) have been officially recognized as a distinct nation within Canada. Their history, culture and establishments are, in multiple ways, different from anything else in Canada. This distinction appears in the place and role given to religion in the education system. Thus, while other provinces (such as Ontario and Alberta) continue to work well with schools, administrative structures and programs anchored in one or more religious faith, Quebec (like Newfoundland and Labrador) has put considerable effort over the last 30 years into secularizing its education system.

Since 1997, the Quebec government has been slowly implementing a series of major legislative and constitutional changes in order to cut the strong ties that have bound schools and Catholic churches from the country's beginnings. These changes were meant to meet a social demand to take religion out of schools in a context of economic and cultural modernization (launched in the 1960s and often termed the 'Quiet Revolution'). The legislative movement developed in 1998 with the transformation of school boards, until then religious, to language school boards. So, as of July 2000, public schools lost their religious status. The same year,

\footnotetext{
${ }^{7}$ This doctoral research protocol has been approved by the Research Ethics Committee of Sherbrooke University.

${ }^{8}$ The appreciative enquiry proposes a dynamic problem-solving process that highlights strengths, achievements and exemplary practices instead of weaknesses. It starts with the positive formulation of a sought-after goal and is developed in four steps, the '4Ds': discovery, dream, design and destiny.
} 
following a reflection that had begun five years earlier, the entire administrative structure and all religious services were abolished. Pastoral and religious animation was replaced by the SCGCIAs.

Schools found themselves with a new obligation, that of 'facilitating the spiritual development of the student to promote self-fulfilment'; this obligation is now stipulated in the Education Act (2000). Hence, if Catholic pastoral animation and Protestant religious animation services disappeared, they were replaced by a new non-religious service responsible for promoting (1) the spiritual development and (2) community involvement of each student, regardless of the student's religious affiliation. This service is the Spiritual Care and Guidance and Community Involvement Service (SCGCIS).

Numerous differences can be identified between this service and the previous Pastoral Animation Service (PAS). PAS professionals had to be trained in theology or religious sciences and given a pastoral mandate from the Diocese. The Catholic Committee of the Superior Council of Education structured their interventions while the religious bodies defined the content of these interventions. During the transformation from PAS to SCGCIS, all administrative structures intended to support and defend the PAS were abolished. There was no more pastoral mandate; the link with religious structures was completely undone. Similarly, training in theology and religious studies was no longer essential, although still available.

Another aspect that changed was the diversity of the animators' training profiles. Today, the Ministry of Education and school boards only ask that SCGCIA applicants have an undergraduate degree, with most courses being in the 'religious or spiritual' and social field (CPNCF 2015). Also, someone can become a SCGCIA with no training simply by committing to complete training subsequently (DFGJ 2006, 29). So, for the last few years, school boards have been able to hire people with no training profile strictly meeting the job description, or even the skills requested. People can become SCGCIAs because of their pre-existing employment relationship with the school board. Some are trained in education, cultural animation, specialized education etc. but, with no common training or shared vision of the service, practices differ significantly from one SCGCIA to another. It then becomes difficult to have and share a professional identity and to defend it against other educational professionals and the school staff's expectations of them. This all weakens the profession and makes it more vulnerable in times of budgetary constraints.

\section{Current professional issues}

\section{Practice setting: constraints, dissemination and insecurity}

Upon implementation of the SCGCIS, the Ministry of Education acknowledged the fact that it entailed 'a challenge to take on collectively in terms of the quality and quantity of workforce needed to ensure the service' 9 . In 2002-2003, the first year of the service in elementary and secondary schools, the more than 400 full-time equivalent (FTE) SCGCIAs working in schools were responsible for an average of 2250 students (SC-SCGCIS 2003, 8). This meant that elementary school SCGCIAs worked in 11 schools, on average; those in high schools worked in 2.5 schools. This report showed that the School Boards used some of the money invested by the

\footnotetext{
${ }^{9}$ SC-SCGCIS $(2004,3)$. This document was not published by the Ministry. The APAVECQ gained access to it via a request for access to information. The current President graciously sent us the document.
} 
Ministry of Education for purposes other than hiring SCGCIA: they hired councillors, paid for further training, travel, or to keep staff already in service in high schools. (SC-SCGCIS 2003, 6, $8,10)$.

Since 2002-2003, the number of SCGIA has dropped drastically. According to ministerial documents (PERCOS) given to us by the APAVECQ, the number of SCGCIAs in 2012-2013 had dropped from 400 to 292.6 FTE. According to our estimates for 2013-2014 and 2014-2015, 20 more SCGCIA positions were abolished. This reduction in the number of SCGCIAs was considerably greater than reductions in other services during the same period. The situation makes the work of SCGCIAs difficult: they spend considerable time travelling between an increasing number of schools, planning group activities with numerous students (repeatable in each class for the same grade), and much less time meeting students individually. This is what SCGCIAs have been saying in general:

\begin{abstract}
In one week, I sometimes spend the equivalent of a day and a half on the road, travelling from one school to another. There, I often don't have access to a private room to drop my things. My office, as I often say, is my car. (Narrative of a day, SCGCIA 8).

Right now, I'm no longer available to talk with students about questions, problem or ideas they may have. I have to organize rallying activities for numerous people, a grade or even the entire school. I don't have that closeness with them that they can come to me to discuss their spirituality. (Narrative of a day, SCGCIA 4)
\end{abstract}

This situation is often referred to by SCGCIAs to explain the importance of the 'community involvement' aspect of their work: it is better accepted in schools, more visible, better suited to a travelling service such as the SCGCIS - and less controversial. Furthermore, as highlighted by Lefebvre $(2007,94)$, 'the community aspect is in keeping with what was an important aspect' of the PAS service. The animator helps to develop the students' altruism and spirit of volunteerism in addition to developing certain aspects of Personal and Social Development, and is thus more welcome by the school staff.

\title{
Focus on community involvement
}

The 'community involvement' aspect of the SCGCIS seems relevant and valued in schools. Cherblanc (2005) had already demonstrated how community involvement is the most important part of the work accomplished by SCGCIAs, the latter therefore meeting the needs of members of the in-school team, making their work visible in each setting with 'citizenship' or environmental activities that are a requirement of study programs in high schools like the international education program (IEP).

The specific aim of the 'community involvement' aspect of the SCGCIA's work is to bring students 'to undertake individual and group projects likely to improve their community and the society around them, with a view to developing social conscience' (DGFJ 2006, 13). The development of social conscience involves valuing justice, peace, honesty, mutual help, respect, tolerance and compassion. These values can be promoted as part of areas of operation such as 'To help others and give freely of one's time' and 'To take a stand against poverty and exploitation (DGFJ 2006, 43). SCGCIAs organize numerous activities with these objective and values: committees (on the environment, citizenship participation, social life); rallies (Club 2/3 Walks, Walk for Water, equitable parades); creations (values mural, intercultural show) and so on. These activities usually get a positive response on social media and APAVECQ websites, schools or 
school boards, and sometimes even in local and regional media. This is why the SCGCIAs in our research say that their main work focuses on community involvement; spiritual life seems to make up only a small part of their activity schedule.

\section{The complexity of spiritual life}

Little research has been conducted on the SCGCIS (Breault 2003; Martineau 2003; Cherblanc 2005, 2010; Lefebvre 2007; CAR 2011; Université de Sherbrooke 2011). That said, all this research has demonstrated the difficulty encountered by stakeholders in defining the 'spiritual life' aspect of their work. In the official document that sets out the guidelines of the SCGCIS, the Quebec Ministry of Education defines it as follows:

Spiritual life is an individual quest within the context of a community, a quest focused on the fundamental questions of the meaning of life and tending toward the construction of a consistent, motivating and continually evolving vision of existence. (DGFJ 2006, 11)

The Ministry is careful to state that it does not intend to define 'spiritual' universally. Here, it proposes to 'define it for the Quebec school system' (DGFJ 2006, 11):

regardless of language and tradition and despite some differences in meaning, this word [spiritual] refers to a reality that transcends human beings, to a vital force that is intimately connected with their day-to-day existence yet opens them to something beyond themselves (DGFJ 2006, 32).

Spiritual life refers to the 'meaning of life', which stems from the answers to 'big questions of existence that most often arise in happy and unhappy life situations' (DGFJ 2006, 32-33). To address these issues, individuals develop what Breton $(1990,17)$ calls the 'unifying pole', or 'the desire to understand all the aspect of one's life (personal, social, universal, cosmic) and to harmonize these components' (quoted in DGFJ 2006, 33). This is close to the description of spiritual life as levels of conscience (Hay and Nye 2006; Eaude 2005 and 2009).

The specific aim of the SCGCIS, linked to spiritual life, is: 'to reflect and experiment in situations designed to help them [students] progress freely in their spiritual lives, with a view to unifying their being in a vision of existence' (DGFJ 2006, 13). The Ministry is also careful to state that the 'vision of existence can be built around what is religious, around a cause like justice or the environment, or around both at once' (DGFJ 2006, 33). It also proposes an educational interpretation of the intervention on this spiritual life with a clear schematic diagram (Figure 1) focused on a 'basic idea': 'To unify one's being'. 


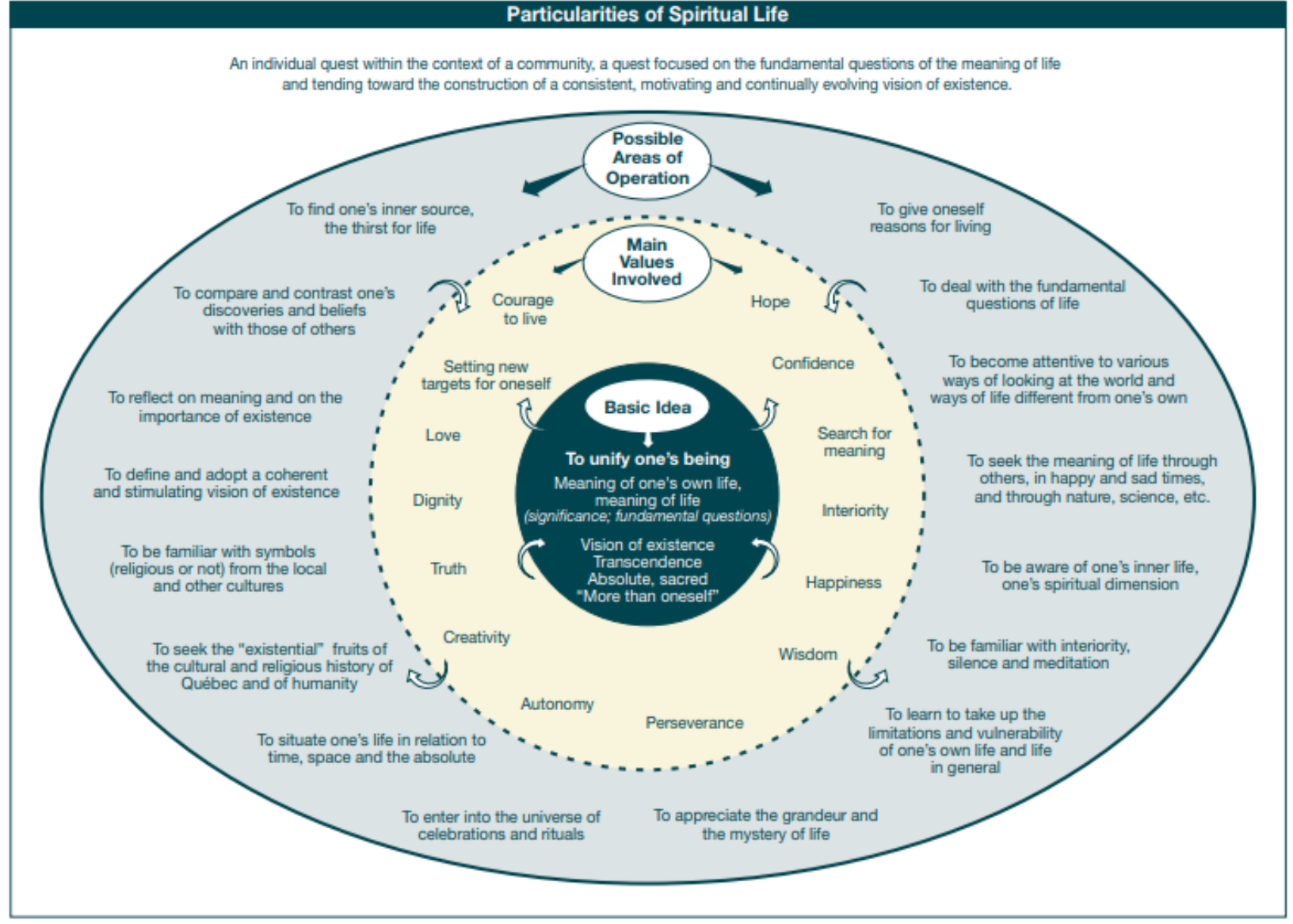

Figure 1 Particularities of spiritual life according to DGFJ (2006)

Revolving around this 'basic idea' are the 'main values involved', e.g: Search for meaning; Interiority; Confidence (DGFJ 2006, 41). These values are promoted in schools with 16 'Possible areas of operation' proposed to SCGCIAs, for example: 'To enter into the universe of celebrations and rituals'; 'To become familiar with interiority, silence and meditation'

Analysis of the various data compared for this article shows the importance of this conceptualization of spiritual animation by SCGCIAs, who often cite it more or less explicitly.

[This activity] allows for an experience that [...] will help [students] evolve freely in their spiritual lives to unify their being as they move on to high school. [...] It is truly 'an individual process within a community that is rooted in the fundamental questions on the meaning of life that fosters the development of a coherent and stimulating vision of existence that is constantly evolving'. Rituals are an extraordinary form that allow us to stop and introduce a moment of reflection, introspection (Narrative of a day, SCGCIA 2).

Here is what I expect [with this activity]: recognition, respect, understanding, love, compassion, work, dedication, interiority and inclusiveness (Narrative of a day, SCGCIA 11).

After analysing the practice narratives submitted by the SCGCIAs and following discussions with APAVECQ representatives about our interpretations of these practices, it is clear that this outlook on spiritual life is very inclusive and subject to a wide variety of interpretations. In their practice, 
SCGCIAs adapt themselves to this diversity, but the situation becomes more delicate when they need to explain what spiritual life means to other members of the in-school team, professionals, teachers, parents and administrators; and to defend their profession in society.

\section{Approach focusing on the action of the SCGCIS: a living laboratory}

Upon reading the above and the designation of the SCGCIS itself, one might think that this service suffers from a split personality: community involvement on one side and spiritual life on the other. But we know, as Eaude $(2005,245)$ argues in referring to Bowlby's (1965) work on attachment, that interiority without alterity could lead to a worthless spirituality that may induce egocentrism. This concern is also acknowledged by Pauchant (2000) as the danger of sinking into a self-actualization race.

In practice, SCGCIAs manage to avoid this 'pathology' by applying the intervention model proposed by the Ministry of Education (2005): the 'living laboratory'. This model is an approach that seems to be specific to SCGCIAs and which would distinguish them from other stakeholders. It aims to situate the SCGCIAs as facilitators, not guides; the students are the ones 'doing the research', 'experimenting' and 'exploring', and should not be taught, or have imposed on them, any 'ideology', 'belief' or 'cause'. 'Respect for students is a core ethic stated in the Ministerial Framework' (DGFJ 2006, 20). To operationalize this laboratory spirit, the SCGCIAs are asked to implement an intervention model: an approach centred on action. This approach consists of three phases (Figure 2): 'acting, reviewing and renewing' (DGFJ 2006, 21). 


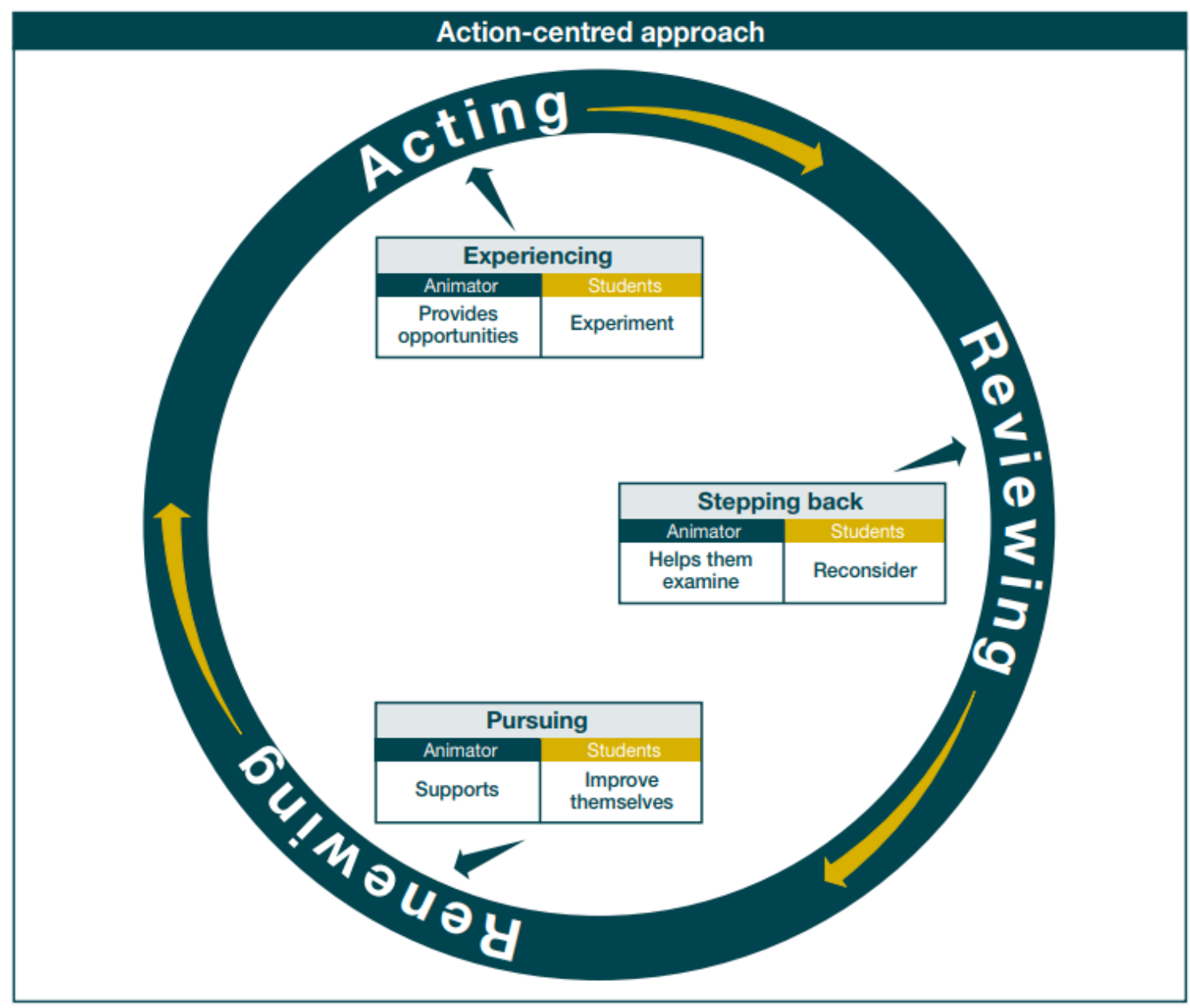

Figure 2 The 'action-centered approach' according to DGFJ $(2006,23)$

Acting consists in having students 'concretely experiencing' different facets of life through activities and setting them in motion. Reviewing 'consists in looking back over one's experience' to bring students to realize how this action engages them (meaning, values, identity), to bring them to 'determine their meaning and scope'. According to the Framework (DGFJ 2006, 22), this phase is 'the most crucial in achieving the objectives of the service'. 'It allows links to be made between two aspects of the service' (DGFJ 2006, 21). Lastly, the renewing phase, aims to learn from the reviewing phase to act in a more enlightened and personal way: 'it is like an extended acting phase to which value has been added'.

In many SCGCIA narratives, and in some APAVECQ documents (APAVECQ 2012), this intervention model is interpreted as a way to combine community involvement and spiritual life in one movement. For SCGCIAs, the 'reviewing' phase thus constitutes the heart of their work in terms of the development of their students' spiritual life.

To my knowledge, I don't do many spiritual activities. Actually, I think we do activities and sometimes look back on these activities during the 'reviewing' phase. That's when the students really have the opportunity to position themselves and define their values 
more consciously. That's how they build their spiritual lives. So, spiritual life is looked at from its overall meaning to life. (Practice narrative, SCGCIA 10)

Reviewing is making way for a search for meaning and interiority. This phase helps to make links, to connect. It conjugates with the notions of freedom of speech, freedom of thought, freedom to progress and deepen. (APAVECQ 2012,4)

Without review, the activities proposed by the spiritual care and guidance and community involvement service are likely to resemble activities that other school staff members could propose. (APAVECQ 2012,9)

From this point of view, spiritual life would be a form of awareness of the meaning of individual and collective actions and an individual standpoint regarding the universe of values and beliefs: identity individuation. In some way, community involvement only finds meaning through this personal review. The latter transforms a (trivial) activity into a (stimulating) action. Community involvement thus seems to be the most important part of the SCGCIAs' activity schedule, but spiritual life is at the heart of the action-based approach that characterizes the service. However, not being a very visible activity, the review phase is often skipped because of lack of time and knowhow.

\section{Toward a professional strategy focused on spiritual life}

After presenting the inconveniences linked to the concept of spiritual life and the advantages linked to community involvement, we understand why SCGCIAs seem very inspired to emphasize the latter aspect of their work. Yet, we will demonstrate that this strategy is not very useful in their professionalization process. Instead, we suggest that SCGCIAs should frame their professional strategy based on the spiritual aspect, while focusing on their current status and role within each practice setting, in an interactionist perspective. This perspective stands out from the classic conflictual strategies used to develop the professionalization process.

\section{Spiritual life includes and extends beyond community involvement}

In the discourses and practices of SCGCIAs, it often appeared that community involvement allowed students to go into action, to act, and that it was then possible to 'work on' the students' spiritual life through individuation ('review') or ethical reflection. Community involvement thus helps to create experiences from which students can extract meaning, values, and a coherent and stimulating vision of the world, provided that they are given time to stop and think. This is what schools actually want: concrete and stimulating actions based on certain social issues and values in keeping with the educational project, the needs of the school and neighbourhood and the content of certain courses. Also, community involvement does not have the negative connotation sometimes associated with spiritual life. The temptation to professionalize the service only around community involvement therefore seems reasonable.

In light of this, we make four arguments: (1) the vision of the spiritual in the Ministerial Framework is much more inclusive than community involvement; (2) activities displayed as being rooted in community involvement are much more spiritual than they seem; (3) focusing on professionalization based on community involvement leads to a risk of competition among other educational actors, while only the spiritual is 'mandatory' and explicitly from the field of SCGCIAs; and (4) focusing professionalization on the spiritual allows for inclusion of the 
community aspect, but in a new and unique stance. Let us examine these arguments in more detail.

First, a semantic analysis of the Ministerial Standards shows how 'we find here the ingredients that promote an individual spirituality embodying social commitment' (Cherblanc 2005, 233). Religiously neutral (but not anti-religious) and anchored in the student/individual, spirituality is that which constitutes the essence of each person, which gives him/her an individuality, a uniqueness even as it is shared with all. This spiritual dimension integrates everything from metaphysics to ethics through the psychosocial processes of individuation. From this point of view, it is clear that community involvement only appears as a manifestation of the spiritual, a 'reinvestment' in the terminology of the Standards (DGFJ 2006, 22). This is only possible if the spiritual has manifested itself in the form of a clarification of values, a positioning in relation to others, to existence, to that which is greater than oneself, and to the 'source within' that motivates our existence in this world (DGFJ 2006, 41). Although community involvement is placed ahead or above the spiritual, it is only as an act of conformity, the acceptance of an action proposed by others and in respect of the directives. Students who march for the right to access water, or against hunger in the world, or for peace, or who make Christmas baskets are not really engaged in the community of citizens if they do so only by rote or in imitation. In order to be able to speak of community involvement, it is necessary for the student to invest her/himself — body and soul — in the action and it must correspond to what s/he wishes, to what s/he thinks and to who s/he is. It must come from within and be a manifestation of a 'unifying core' to make it truly educational. As the Standards make clear:

This is not only a matter of 'doing,' but also of knowing the underlying reasons for action, as well as its consequences. If people are not aware of why they are involved in something, their involvement runs the risk of being sporadic or, what is worse, of perpetuating the unfortunate situations that sparked their initial involvement. (DGFJ 2006, 35)

Furthermore, what drives community involvement and what we could summarize with the expression 'concern for others' is fundamentally spiritual and religious in nature. It is true that numerous philosophical trends (such as humanism) and non-religious organizations now promote these values of altruism, charity, and assistance, but as highlighted in the Framework (DGFJ $2006,35)$, community involvement is fundamentally rooted in a conviction - a belief - that we must take care of others. Without this deep conviction, the entire social, humanistic and democratic fabric crumbles. This is why, theoretically, we think we can claim that community involvement is included in spiritual life and depends on the vigour of the latter, its awareness. Therefore, we can declare that spiritual life includes and extends beyond community involvement.

Then, in light of this understanding of the interaction between community involvement and spiritual life, it seems clear that community involvement activities can only be truly engaging if they are part of a process of spiritual life animation. Indeed, practically, action that is committed to the community must represent the student's vision of the world, participate in it and enrich it. Otherwise, it is disembodied and meaningless and is more of an occupation, leisure activity, or even a form of entertainment. Other school officers are responsible for animating the leisure, sports and cultural activities of students. Whether they are recreational technicians, cultural animators or student life representatives, there are various educational actors who can encourage citizen involvement, sport, art or cultural activities effectively. Thus, for SCGCIAs to focus primarily on the 'community involvement' aspect of their work seems rather risky to us 
given the competition from these other stakeholders ${ }^{10}$. Only the SCGCIAs have a specific mandate to work on the 'spiritual life' aspect of community involvement: it is their professional 'added-value'.

Finally, what we believe particularly fosters professionalization focused on the spiritual is that the Education Act (EA) (Sections 6, 36 and 226) and Basic School Regulation (Sections 4 and 5) require schools to provide a Spiritual Care and Guidance and Community Involvement Service (SCGCIS). Section 36 of the EA recognizes that 'facilitating the spiritual development' of students will 'promote self-fulfilment', and that this is a duty of public schools. Sections 6 and 226 mention that schools must offer all students services for spiritual care and guidance and community involvement, and that all students have a right to this regardless of their religious affiliations. Only SCGCIAs can support school staff in this new requirement. This, again, is why it seems more strategic, especially under budgetary constraints, to focus the professional identity of SCGCIAs on spiritual life rather than on community involvement.

\section{Conclusion}

Having presented the background that led to the development of the SCGCIS, we noted how the SCGCIAs responsible for it are questioning their professional identity. This introspection is fuelled by a growing awareness that many different people currently offer this service, and have different training backgrounds and understanding of the terms of reference defining their work. SCGCIAs are now working towards professionalization which they deem essential to their very survival. Nevertheless, they are using professional strategies that do not seem to fully reflect their current reality and power. Thus, rather than designing their profession around community involvement, as the government seems to desire, we have instead suggested that a perspective focused on the spiritual seems more promising. Indeed, SCGCIAs are already professionals, in the sense of interactionist sociology (Demazière and Gadéa 2009), because:

- they have specific knowledge, even though it does not come from universities or disciplinary experts;

- they work in a specific field recognized by the Education Act and by related professional groups: spiritual life and community involvement stem from it;

- they have the support of a professional association that is working to have their unique skill sets recognized by their members, the professional group to which they belong, and the state.

What do SCGCIAs need in order to establish their professionalism? Two elements essentially: a professionalized discourse and a more formal conceptualization of knowledge of spirituality. First, their identity must be well thought out by themselves and not just reflected from others. Second, it is important to make their practical knowledge 'explainable' and explained in order for it to be included in introductory and continuous professional development processes. Most importantly, their practical knowledge must be communicable. These are the issues on which the APAVECQ must work.

\footnotetext{
${ }^{10}$ The reduction and even disappearance of these student life and recreational specialists in schools since the 1990 s indicates that this is not the way to go for job security.
} 
Currently, the strategy currently employed by SCGCIAs to define themselves, especially within their professional association, tends to await government instructions (e.g. policies, task definitions, SCGCIA training and hiring requirements) and to follow its lead on 'community involvement'. Thus, decreasing SCGCIAs' dependence on the Ministry of Education is essential in defining who they are and what they must do. From this perspective, the development of real professional autonomy is appropriate so that nothing stops people from believing that SCGCIAs can one day offer their professional spiritual expertise outside the school setting.

\section{Notes on contributors}

\section{Dr Jacques Cherblanc}

Jacques Cherblanc is Professor of Ethics and Religion at the Université du Québec à Chicoutimi (Canada). He is a socio-anthropologist specializing in the place and function of religion and spirituality in health institutions and public schools in Quebec. He is associated with the Centre for Inter-University Research on the Learning Framework for the Teaching Profession (CRIFPE) and is Director of the Laboratory of Expertise and Research in Ritual and Symbolic Anthropology (LERARS). He has published widely, including Rites et Symboles Contemporains (2011, PUQ).

\section{Marie-Hélène Risdon}

Marie-Anne Risdon has many years' experience as both pastoral animator and consultant in elementary and high schools. She was one of the founders of the Spiritual Care and Guidance and Community Involvement Service (2000-2004) and subsequently coordinated the service for the Ministère de l'Éducation du Québec (provincial education department) until she retired in 2015. She is now a researcher in the LERARS laboratory.

\section{References}

APAVECQ. (2012) La relecture : La maîtriser, La pratiquer. Internal Publication.

Argyris, C., Putman, R. et Mclain Smith, S. (1985) Action Science : Concepts, methods, and skills for research and intervention. San Francisco, CA : Jossey-Bass.

Cherblanc, J. (2010) «Modernité, religion et éducation au Québec : de la régulation religieuse de l'éducation à la régulation politique du spirituel ». Robert Mager et Serge Cantin (Dir.) Modernité et religion au Québec : où en sommes-nous?, Québec, PUL : 293-306.

Cherblanc, J. (2005) Théorisation ancrée du religieusement acceptable au Québec : le service d'animation spirituelle et d'engagement communautaire dans les écoles secondaires francophones de l'Île de Montréal. Thèse de doctorat en science des religions, Université du Québec à Montréal, et en science politique, Institut d'études politiques de Bordeaux.

Bertaux, D. (1976). Histoires de vie ou récits de pratique? Paris: Centre d'études des mouvements sociaux.

Best, R. (ed.). (1996). Education, Spirituality and the Whole Child. New-York: Continuum International Publishing Group Ltd.

Breault, I. (2003) Favoriser l'ouverture à la liberté, l'autonomie et la transcendance dans l'approche du service non confessionnel d'animation à la vie spirituelle et à l'engagement communautaire. Mémoire de maîtrise en théologie, Université du Québec à Trois-Rivières, Trois-Rivières.

Breton, J.-C. (1990). Approche contemporaine de la vie spirituelle, Québec : Bellarmin : 17. 
CPNCF [Comité patronal de négociation pour les commissions scolaires francophones]. (2015) Plan de classification. Personnel professionnel. Disponible à : http://cpn.gouv.qc.ca/cpncf/plans-de-classification/

CAR [Comité sur les affaires religieuses]. (2011) Conceptions du spirituel et du religieux chez les animatrices et animateurs de vie spirituelle et d'engagement communautaire. Synthèse de recherche. Ministère de l'Éducation, du Loisir et du Sport.

Carr, D. and J. Haldane (ed.). (2003). Spirituality, Philosophy and Education. Abingdon: Routledge.

Comité sur les affaires religieuses (2007). Secular schools in Québec : a necessary change in institutional culture brief to the Minister of education, recreation and sports : Brief to the Minister of Education, Recreation and Sports. Québec: Gouvernement du Québec, Ministère de l'Éducation, du Loisir et du Sport.

Cooperrider, D. L., and Whitney, D. (2005) Appreciative inquiry: A positive revolution in change. San Francisco, CA : Berrett-Koehler Publishers.

Demazière D. and Gadéa C. (2009), Sociologie des groupes professionnels, Acquis récents et nouveaux défis, Paris : La Découverte.

De Souza, M. (2016). Spirituality in Education in a Global, Pluralised World, Abingdon: Routledge

DGFJ (Direction générale de la formation des jeunes, Ministère de l'éducation). (2006) Developping the Inner Life and Changing the World. The Spiritual Care and Guidance and Community Involvement Service, Minsterial Framework. Québec : Gouvernement du Québec.

Eaude, T. (2005). Strangly familiar? - Teachers making sense of youg children's spiritual development. Early Years, 25(3): 237-248.

Eaude, T. (2009). Happiness, emotional well-being and mental health - What has children's spirituality to offer? International Journal of Children's Spirituality, 14(3): 185-196.

Erriker, J., C. Ota and C. Erriker. (2001). Spiritual education : cultural, religious, and social differences : new perspectives for the 21 st century. Brighton [England] ; Portland, Oregon : Sussex Academic Press.

Garfinkel, H. (1984). Studies in Ethnomethodology. Cambridge: Polity press.

Glazer, S. (Ed.). (1999). The heart of learning: Spirituality in education. New York: Penguin.

Gouvernement du Québec (2017) Basic school regulation for preschool, elementary and secondary education. Publication Québec. http://legisquebec.gouv.qc.ca/en/ShowDoc/cr/I-13.3,\% 20r.\%208

Hay, D. and R. Nye : (2006). The spirit of the child ( $2^{\mathrm{d}}$ ed). London: Jessica Kingsley Publishers. $\left(1^{\text {st }}\right.$ ed: 1998$)$

Lefebvre, S. (2007) Gestion de la diversité religieuse dans l'espace scolaire : Nouvelles pratiques. Rapport présenté au Secrétariat aux affaires religieuses, Ministère de l'Éducation, du Loisir et du Sport. Disponible sur : http://www.observatoiredesreligions.ca

Education Act, L.Q. 2000, c. 3, art. 36. http://legisquebec.gouv.qc.ca/en/ShowDoc/cs/I-13.3/

Martineau, J. (2003) Le service d'animation spirituelle et d'engagement communautaire. Enjeux et perspectives. Maitrise en théologie, Université du Québec à Trois-Rivières, Trois-Rivières.

Miller, J. P. and Karsten, S. and Denton, D.(2005). Holistic Learning and Spirituality in Education: Breaking New Ground. Albany: State University of New York Press.

Paillé:, and Mucchielli, A. (2003) L'analyse qualitative en sciences humaines et sociales. Paris : Armand Colin.

Pauchant, T. (2000). Pour un management éthique et spirituel: Défis, cas, outils et questions. Montréal: Fides / Presses HEC.

Roehlkepartain, E. C., King, P. E., Wagener, L. and Benson, P. L. (2006). The handbook of spiritual development in childhood and adolescence. Thousand Oaks, CA: SAGE Publications, Inc. doi: 10.4135/9781412976657

Sarfati Larson, M. (1997) The Rise of Professionalism: A Sociological Analysis. Berkeley: University of California Press.

Schön, D. (1983) The Reflective Practitioner: How Professionals Think in Action. London, : Temple Smith.

Secrétariat aux affaires religieuses. (2001) Service d'animation spirituelle et d'engagement communautaire. Bilan des consultations et des sessions tenues au printemps 2001 et suites à donner. Québec, Ministère de l'éducation.

SC-SASEC [Sous-comité sur la mise en œuvre du service d'animation spirituelle et d'engagement communautaire du Comité directeur conjoint MEQ-CS sur les plans stratégiques et la reddition de comptes]. (2003) Rapport d'étape. Bilan d'une collecte de données sur les ressources humaines et financières affectées au service. Année 2002-2003. Gouvernement du Québec.

SC-SASEC [Sous-comité sur la mise en œuvre du service d'animation spirituelle et d'engagement communautaire du Comité directeur conjoint MEQ-CS sur les plans stratégiques et la reddition de comptes]. (2004) Rapport final. Rapport sur la situation du service d'animation spirituelle et d'engagement communautaire depuis sa création en juillet 2001. Un service apprécié... qui n'a pas atteint tout son potentiel! Gouvernement du Québec. 
Université de Sherbrooke. (2011) Sondage sur le service d'animation à la vie spirituelle et à l'engagement communautaire. Faculté de théologie et d'études religieuses en collaboration avec l'APAVECQ.

Wane, N. N. Manyimo E. L., Ritskes, E. J. (2011). Spirituality, Education and Society. Berlin: Springer.

Wenman, T. (2001). Reporting the Spiritual in Primary Schools, International Journal of Children's Spirituality, 6:3, 311-324, DOI: 10.1080/13644360120100487

The authors declare that they have no conflict of interest.

\section{Correspondence to: Jacques Cherblanc Email: Jacques_Cherblanc@uqac.ca}

Université du Québec à Chicoutimi (UQAC) Centre for Inter-University Research on the Learning Framework for the Teaching ProfessionLaboratory of Expertise and Research in Ritual and Symbolic Anthropology 555 De l'Université Boulevard Chicoutimi, QC, Canada, G7S 2M2 